\title{
Silver-catalyzed synthesis of $\beta$-fluorovinylphosphonates by phosphonofluorination of aromatic alkynes
}

\author{
Yajing Zhang ${ }^{1}$, Qingshan Tian², Guozhu Zhang ${ }^{2}$ and Dayong Zhang ${ }^{* 1}$
}

\section{Full Research Paper}

Address:

${ }^{1}$ School of Science, China Pharmaceutical University, 24

Tongjiaxiang, Nanjing 210000, P. R. China and ${ }^{2}$ State Key Laboratory

of Organometallic Chemistry, Shanghai Institute of Organic Chemistry,

Chinese Academy of Sciences, 345 Lingling Road, Shanghai 200032,

P. R. China

Email:

Dayong Zhang* - zhangdayong@cpu.edu.cn

* Corresponding author

Keywords:

$\beta$-fluorovinylphosphonates; fluorine atom transfer; P-centered radical; silver catalysis; three-component reaction
Beilstein J. Org. Chem. 2020, 16, 3086-3092.

https://doi.org/10.3762/bjoc. 16.258

Received: 28 September 2020

Accepted: 07 December 2020

Published: 18 December 2020

Associate Editor: B. Stoltz

(C) 2020 Zhang et al.; licensee Beilstein-Institut. License and terms: see end of document.

\begin{abstract}
A silver-catalyzed three-component reaction involving alkynes, Selectfluor ${ }^{\circledR}$, and diethyl phosphite was employed for the one-pot formation of $\mathrm{C}\left(\mathrm{sp}^{2}\right)-\mathrm{F}$ and $\mathrm{C}\left(\mathrm{sp}^{2}\right)-\mathrm{P}$ bonds to provide an efficient access to $\beta$-fluorovinylphosphonates in a highly regio- and stereoselective manner under mild reaction conditions. This reaction is operationally simple and offers an excellent functional group tolerance as well as a broad substrate scope that includes both terminal and internal alkynes. The reaction proceeded through the oxidative generation of a P-centered radical and subsequent fluorine atom transfer.
\end{abstract}

\section{Introduction}

As one of the most important topics in organic chemistry, the introduction of fluorine and phosphorus atoms into double bonds is an attractive approach for the synthesis of a variety of valuable organic compounds [1-7]. Although progress has been achieved in the formation of $\mathrm{C}\left(\mathrm{sp}^{2}\right)-\mathrm{F}$ bonds from various substrates [8-13], new catalytic reactions to introduce fluorine and phosphorus are seldom reported.

Among the strategies for constructing diverse alkenes containing two-heteroatom bonds, such as disulfonylation [14-16], heterohalogenation [17-20], bis(trifluoromethyl)thiolation [21], and phosphorylation [22], the direct heterodifunctionalization of alkynes using three-component reactions is the most rapid and convenient one (Scheme 1). Although studies on alkyne difunctionalization are ongoing [23], the successful attachment of a fluorine atom to the resulting alkene through transition metal catalysis remains a challenge. In particular, the phosphonofluorination of alkynes for the introduction of two strong electronwithdrawing groups into double bonds has not yet been reported. With our continuous interest in, and inspiration from the 
a) disulfonylation

$$
\mathrm{R}^{1} \equiv+\mathrm{ArSO}_{2} \mathrm{Na} \stackrel{\mathrm{Cu}, \mathrm{BrCF}_{2} \mathrm{CO}_{2} \mathrm{Et}}{\longrightarrow} \mathrm{R}^{1} \stackrel{\mathrm{SO}_{2} \mathrm{Ar}}{\mathrm{SO}_{2} \mathrm{Ar}}
$$

b) heterohalogenation

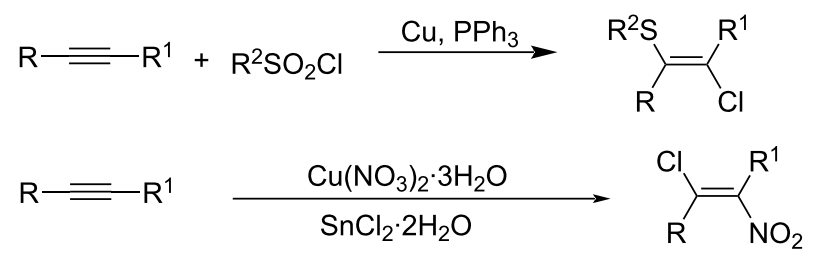

c) silaboration

$\mathrm{R}^{1} \equiv \mathrm{R}^{2}+\mathrm{PhMe}_{2} \operatorname{SiBpin} \longrightarrow \mathrm{Cu} \longrightarrow \mathrm{SiMe}_{2} \mathrm{Ph} \underbrace{\mathrm{Bpin}}_{\mathrm{R}^{1}}$

d) bis(trifluoromethyl)thiolation

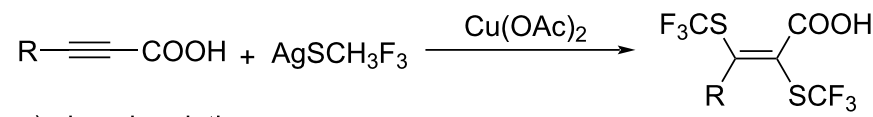

e) phosphorylation

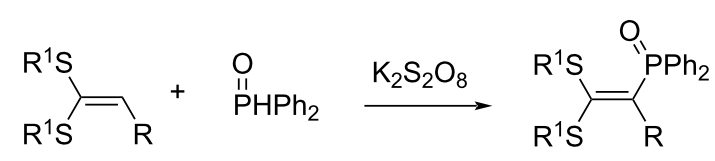

this work:

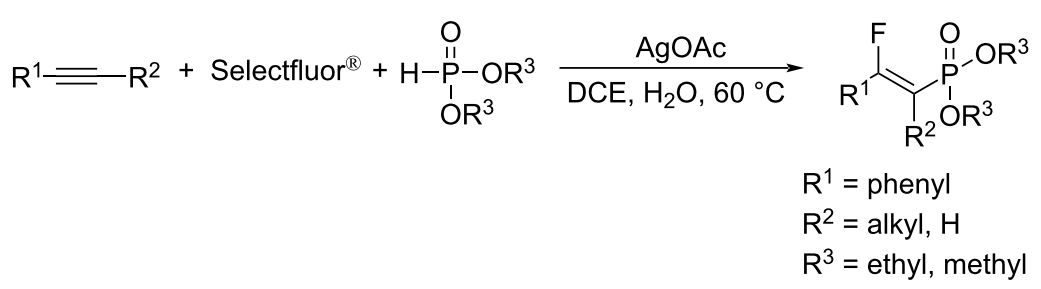

Scheme 1: Metal-catalyzed difunctionalization of unsaturated carbon-carbon bonds.

well-established transition metal-catalyzed radical difunctionalization of unsaturated carbon-carbon bonds, specifically the work of Li's group and others concerning the silver-catalyzed phosphonofluorination of alkenes [24-26], we herein present a general silver-catalyzed regio- and stereoselective phosphonofluorination of alkynes using Selectfluor ${ }^{\circledR}$ and phosphonates as reactants (Scheme 1). This new silver-catalyzed approach to fluorinated vinylphosphonates from simple and commercially available alkynes proceeds under mild conditions with high stereoselectivity, and thus enabling the rapid construction of molecular complexity.

\section{Results and Discussion}

We investigated the reaction of phenylacetylene (1a), Selectfluor $^{\circledR}$, and diethyl phosphite to afford $\beta$-fluorovinylphospho- nates under mild conditions. First, we examined the catalytic activity of various transition metal catalysts, including $\mathrm{Au}, \mathrm{Ag}$, $\mathrm{Cu}, \mathrm{Rh}$, and $\mathrm{Pd}$ complexes (Supporting Information File 1). Among these metal salts, silver salts, especially AgOAc, were the most effective catalysts for generating the desired product 2a (Table 1, entries 1-8). The influence of different reaction temperatures on the reaction outcome was also investigated. At room temperature, the product $\mathbf{2 a}$ was obtained in $72 \%$ yield (Table 1, entry 8). Increasing the reaction temperature to $60{ }^{\circ} \mathrm{C}$ further improved the yield to $79 \%$ (Table 1, entry 9), although only a low yield was obtained when the reaction was performed at $100{ }^{\circ} \mathrm{C}$ (Table 1, entry 10). The reaction outcome was greatly affected by the solvent used. We carried out this reaction in DCE as the only solvent, and no product was obtained (Table 1, entry 15). The use of EtOAc and $\mathrm{H}_{2} \mathrm{O}$ or of THF and 
Table 1: Optimization of the reaction conditions.

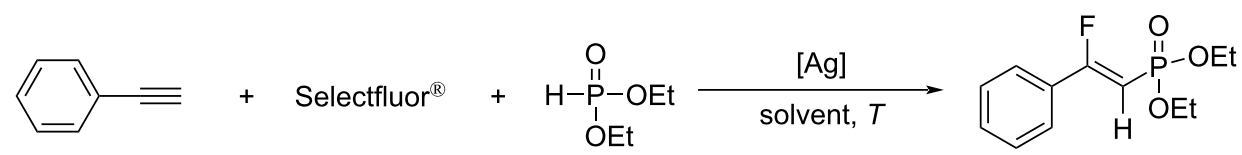

$1 \mathrm{a}$

$2 a$

\begin{tabular}{|c|c|c|c|c|}
\hline entrya & catalyst & solvent & $T\left({ }^{\circ} \mathrm{C}\right)$ & yield $(\%)^{b}$ \\
\hline 1 & $\mathrm{Ag}_{2} \mathrm{CO}_{3}$ & $\mathrm{DCE}, \mathrm{H}_{2} \mathrm{O}$ & rt & 38 \\
\hline 2 & $\mathrm{AgF}$ & DCE, $\mathrm{H}_{2} \mathrm{O}$ & $\mathrm{rt}$ & 24 \\
\hline 3 & AgOTf & DCE, $\mathrm{H}_{2} \mathrm{O}$ & $\mathrm{rt}$ & 34 \\
\hline 4 & $\mathrm{AgSbF}_{6}$ & DCE, $\mathrm{H}_{2} \mathrm{O}$ & $\mathrm{rt}$ & 38 \\
\hline 5 & $\mathrm{AgNO}_{3}$ & DCE, $\mathrm{H}_{2} \mathrm{O}$ & $\mathrm{rt}$ & 58 \\
\hline 6 & $\mathrm{AgNO}_{3}$ & $\mathrm{DCE}, \mathrm{H}_{2} \mathrm{O}, \mathrm{AcOH}$ & $\mathrm{rt}$ & 62 \\
\hline 7 & $\mathrm{AgNO}_{3}$ & DCE, $\mathrm{H}_{2} \mathrm{O}$, TFA & $\mathrm{rt}$ & 63 \\
\hline 8 & $\mathrm{AgOAc}$ & $\mathrm{DCE}, \mathrm{H}_{2} \mathrm{O}$ & $\mathrm{rt}$ & 72 \\
\hline 9 & $\mathrm{AgOAc}$ & $\mathrm{DCE}, \mathrm{H}_{2} \mathrm{O}$ & 60 & 79 \\
\hline 10 & $\mathrm{AgOAc}$ & $\mathrm{DCE}, \mathrm{H}_{2} \mathrm{O}$ & 100 & 20 \\
\hline 11 & $\mathrm{AgOAc}$ & $\mathrm{EtOAc}, \mathrm{H}_{2} \mathrm{O}$ & 60 & 33 \\
\hline 12 & $\mathrm{AgOAc}$ & $\mathrm{THF}, \mathrm{H}_{2} \mathrm{O}$ & 60 & 40 \\
\hline 13 & $\mathrm{AgOAc}$ & $\mathrm{CH}_{3} \mathrm{CN}, \mathrm{H}_{2} \mathrm{O}$ & 60 & - \\
\hline 14 & $\mathrm{AgOAc}$ & DMF & 60 & - \\
\hline 15 & $\mathrm{AgOAc}$ & DCE & 60 & - \\
\hline 16 & - & DCE, $\mathrm{H}_{2} \mathrm{O}$ & 60 & - \\
\hline
\end{tabular}

aReaction conditions: $1 \mathrm{a}(0.2 \mathrm{mmol})$, silver salt $(0.02 \mathrm{mmol})$, diethyl phosphite $(0.4 \mathrm{mmol})$, and Selectfluor ${ }^{\circledR}\left(0.4 \mathrm{mmol}^{\mathrm{m}}\right)$ were stirred in the reaction solvent $(1 \mathrm{~mL}: 1 \mathrm{~mL})$ at $60{ }^{\circ} \mathrm{C}$ for $24 \mathrm{~h}$ under $\mathrm{N}_{2}$. ${ }^{\text {blsolated yield. }}$

$\mathrm{H}_{2} \mathrm{O}$, instead of DCE and $\mathrm{H}_{2} \mathrm{O}$, afforded the monofluoroalkene 2a in only a low yield (Table 1, entries 11 and 12), whereas the product 2a was not obtained when using acetonitrile and $\mathrm{H}_{2} \mathrm{O}$ or when using DMF (Table 1, entries 13 and 14). Similarly, the desired product was not obtained in the absence of a silver catalyst (Table 1, entry 16). The extensive screening of these reaction parameters revealed that the treatment of the alkynes 1 with Selectfluor ${ }^{\circledR}$, diethyl phosphite, and silver acetate as the catalyst as well as DCE/ $\mathrm{H}_{2} \mathrm{O} 1: 1$ as the solvent at $60{ }^{\circ} \mathrm{C}$ afforded the optimal result.

The substrate scope of the reaction was investigated under the optimized reaction conditions. As shown in Scheme 2, various $\beta$-fluorovinylphosphonates could be conveniently and efficiently obtained using the developed method. Aromatic alkynes bearing various functional groups, including both electron-rich and electron-deficient moieties at the para- and meta-positions generally reacted smoothly to afford the desired products $\mathbf{2 a - 0}$ in moderate to good yield. An aromatic alkyne possessing a $\mathrm{Cl}$ substituent at the ortho-position also reacted smoothly to provide the corresponding product $\mathbf{2 k}$ in $56 \%$ yield. Substrates containing a range of functional groups, including halides $(\mathrm{F}$,
$\mathrm{Cl}$, and $\mathrm{Br}$ ), $\mathrm{CF}_{3}$, and even ester groups, were amenable to this transformation. The reaction was also compatible with a $\mathrm{CN}$ group to afford the corresponding product $2 \mathrm{n}$ in $69 \%$ yield. Heteroaromatic alkynes, such as 2-ethynylpyridine and 2-ethynylthiophene, did not undergo the reaction to form $\mathbf{2 r}$ and 2s. Internal aromatic alkynes were tolerated and generated the desired products $\mathbf{2 p}$ and $\mathbf{2 q}$ in moderate yield. Aliphatic alkynes, such as (prop-2-yn-1-yl)benzene and (but-3-yn-1yl)benzene, afforded the corresponding products in an extremely low yield. Another H-phosphonate, namely dimethyl phosphite, was a suitable substrate for this transformation and provided the products 3 in good yield (Scheme 3).

The well-known radical-trapping reagent 2,2,6,6-tetramethylpiperidine- $N$-oxyl (TEMPO) was used to gain an insight into the reaction mechanism. As illustrated in Scheme 4, the addition of 1 equiv TEMPO suppressed the reaction. In addition, 4-ethynylaniline (1f) reacted with Selectfluor ${ }^{\circledR}$ and dimethyl phosphite under the optimized conditions to afford the expected product in $13 \%$ yield, and no competitive electrophilic compound $\mathbf{4 f}$ was observed. These findings imply that the transformation may involve a radical process rather than an ionic process. 


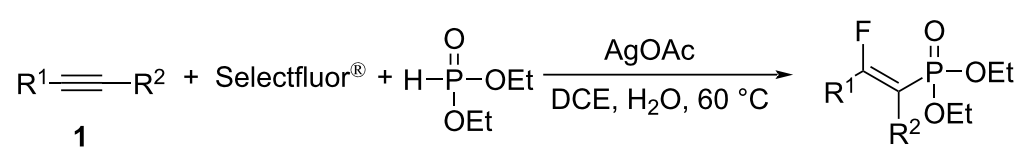<smiles>CCOP(=O)(C=C(F)c1ccccc1)OCC</smiles>

2a, $79 \%$ (gram scale: $67 \%$ )<smiles>CCOP(=O)(/C=C(\F)c1ccc(C(C)(C)C)cc1)OCC</smiles>

2d, $75 \%$<smiles>CCOP(=O)(C=C(F)c1ccc(F)cc1)OCC</smiles>

2g, $77 \%$<smiles>CCOP(=O)(C=C(F)c1cccc(Cl)c1)OCC</smiles>

2j, $71 \%$<smiles>CCOP(=O)(/C=C(\F)c1ccc(C(F)(F)F)cc1)OCC</smiles>

$2 \mathrm{~m}, 85 \%$<smiles>CCOP(=O)(OCC)C(C)=C(F)c1ccccc1</smiles>

2p, $60 \%$ E/Z 11:89a<smiles>CCOP(=O)(C=C(F)c1ccc(C)cc1)OCC</smiles>

2b, $68 \%$<smiles>CCOP(=O)(C=C(F)c1ccc(OC)cc1)OCC</smiles>

2e, $60 \%$<smiles>CCOP(=O)(C=C(F)c1cccc(F)c1)OCC</smiles>

2h, $80 \%$<smiles>CCOP(=O)(C=C(F)c1ccccc1Cl)OCC</smiles>

$2 k, 56 \%$<smiles>CCOP(=O)(C=C(F)c1cccc(C)c1)OCC</smiles>

2c, $67 \%$<smiles>CCOP(=O)(/C=C(\F)c1ccc(-c2ccccc2)cc1)OCC</smiles>

2f, $69 \%$<smiles>CCOP(=O)(C=C(F)c1ccc(Cl)cc1)OCC</smiles>

2i, $83 \%$<smiles>CCOP(=O)(/C=C(\F)c1ccc(Br)cc1)OCC</smiles>

2I, $68 \%$<smiles>CCOC(=O)c1ccc(C(F)=CP(=O)(OCC)OCC)cc1</smiles>

2n, $69 \%$

2o, $74 \%$<smiles>CCOP(=O)(OCC)C(CC)=C(F)c1ccccc1</smiles><smiles>CCOP(=O)(OCC)C(F)=C(F)c1ccccn1</smiles>

$2 r, 0 \%$<smiles>CCOP(=O)(OCC)C(F)=C(F)c1cccs1</smiles>

2s, $0 \%$

$2 q, 51 \%$

$E / Z 3: 97^{a}$

Scheme 2: Substrate scope for the synthesis of the $\beta$-fluorovinylphosphonates 2 using diethyl phosphite. Reaction conditions: aromatic alkyne 1 $(0.2 \mathrm{mmol}), \mathrm{AgOAc}(0.02 \mathrm{mmol})$, diethyl phosphite $(0.4 \mathrm{mmol})$, and Selectfluor ${ }^{\circledR}(0.4 \mathrm{mmol})$ were stirred in DCE/ $\mathrm{H}_{2} \mathrm{O} 1 \mathrm{~mL}: 1 \mathrm{~mL}$ at $60{ }^{\circ} \mathrm{C}$ for $24 \mathrm{~h}$ under $\mathrm{N}_{2}$. The yields of the isolated products are shown. aThe $E / Z$ ratio was determined by ${ }^{1} \mathrm{H}$ NMR analysis of the reaction mixture after the reaction reached completion.

On the basis of previous reports [23-26], we propose a radical mechanism involving the silver promoter, as illustrated in Scheme 5. In this mechanism, $\operatorname{Ag}(\mathrm{I})$ was oxidized by selectflour to generate $\mathrm{Ag}(\mathrm{III}) \mathrm{F}$. Subsequently, ethyl phosphite is oxidized by $\mathrm{Ag}(\mathrm{III}) \mathrm{F}$ to generate a P-centered radical (INT-I) and $\operatorname{Ag}(\mathrm{II}) \mathrm{F}$. The electrophilic phosphonyl radical addition to the triple bond of 1a generates the vinyl-free radical INT-II, which is subsequently trapped by $\mathrm{AgF}$ (II) to afford the corresponding product $\mathbf{2 a}$. The vinyl radical INT-II stabilizes the unpaired electron through resonance, and INT-II is more stable 


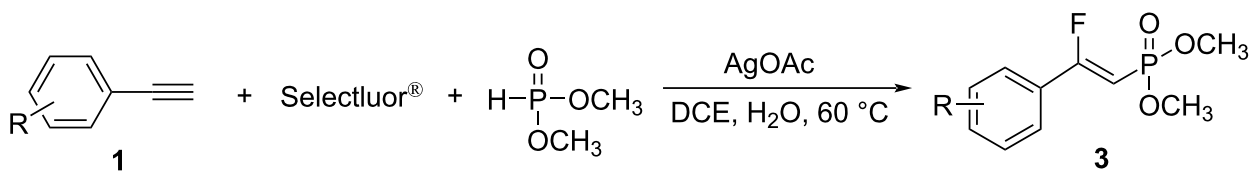<smiles>COP(=O)(C=C(F)c1ccccc1)OC</smiles>

3a, $75 \%$<smiles>COP(=O)(C=C(F)c1ccc(C)cc1)OC</smiles>

3b, $60 \%$<smiles>COP(=O)(C=C(F)c1ccc(F)cc1)OC</smiles>

3c, $69 \%$<smiles>COP(=O)(C=C(F)c1ccc(Br)cc1)OC</smiles>

3d, $72 \%$

Scheme 3: Substrate scope for the synthesis of the $\beta$-fluorovinylphosphonates 3 using dimethyl phosphite. Reaction conditions: aromatic alkyne 1 $(0.2 \mathrm{mmol}), \mathrm{AgOAc}(0.02 \mathrm{mmol})$, dimethyl phosphite $(0.4 \mathrm{mmol})$, and Selectfluor ${ }^{\circledR}(0.4 \mathrm{mmol})$ were stirred in DCE/ $\mathrm{H}_{2} \mathrm{O} 1 \mathrm{~mL}: 1 \mathrm{~mL}$ at $60{ }^{\circ} \mathrm{C}$ for $24 \mathrm{~h}$ under $\mathrm{N}_{2}$. The yields of the isolated products are shown.

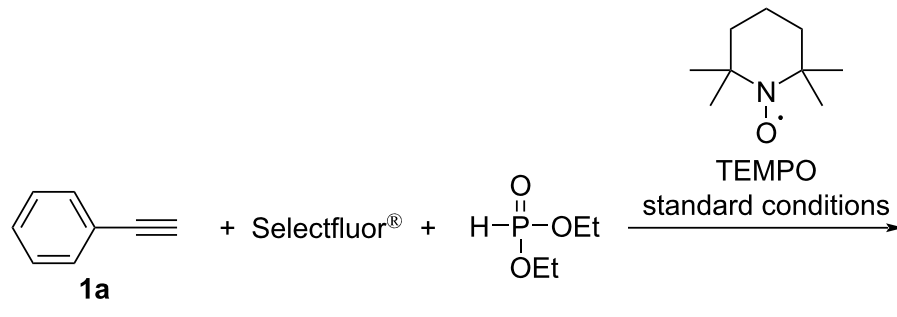<smiles>CCOP(=O)(/C=C(\F)c1ccccc1)OCC</smiles>

$2 a$

trace

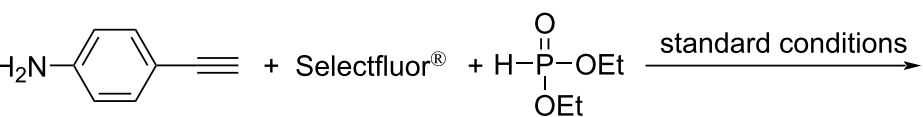

$1 f$

OEt

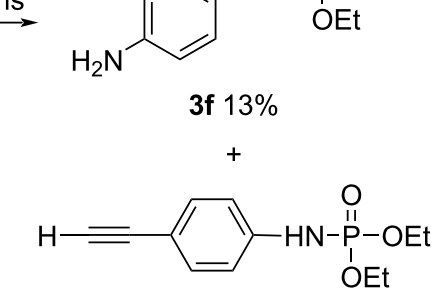

4f, $0 \%$

Scheme 4: Radical-trapping experiments.

than INT-III [27,28]. Finally, we obtained the Z-configured product with respect to the aryl and phosphonyl groups.

We also performed control experiments under standard conditions to determine whether diethyl fluorophosphonate is a key intermediate in the reaction with aromatic alkynes. Based on a method by Gupta et al. [29], we obtained diethyl fluorophosphonate. Subsequently, the diethyl fluorophosphonate did not react with an aromatic alkyne in the desired phosphonofluorination so that no product was obtained (Scheme 6) [30].

\section{Conclusion}

In conclusion, a novel method for the synthesis of $\beta$-fluorophosphonates through the direct phosphonofluorination of alkynes with Selectfluor ${ }^{\circledR}$ and H-phosphonates under mild reaction conditions has been successfully developed. Owing to its broad 


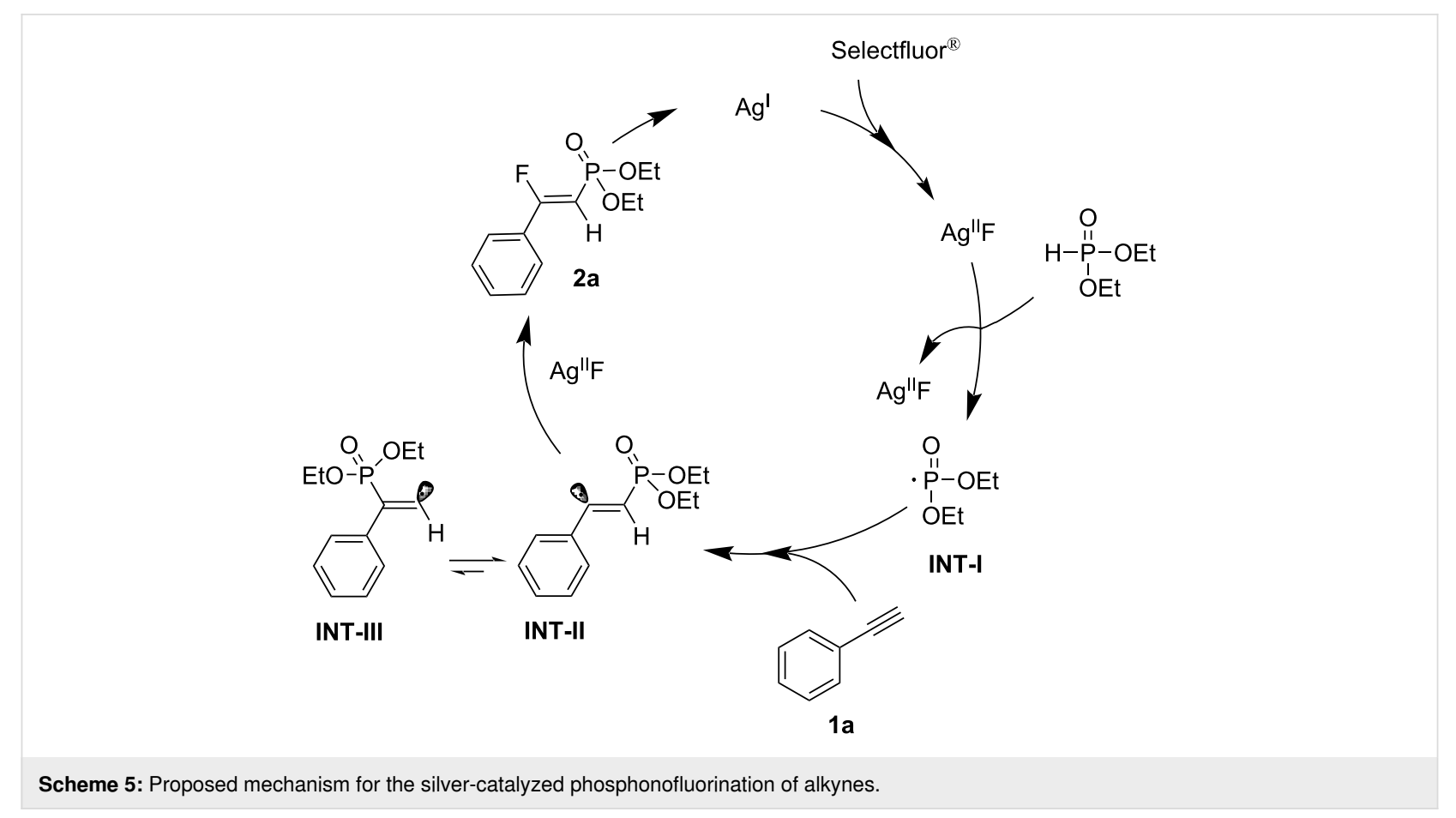

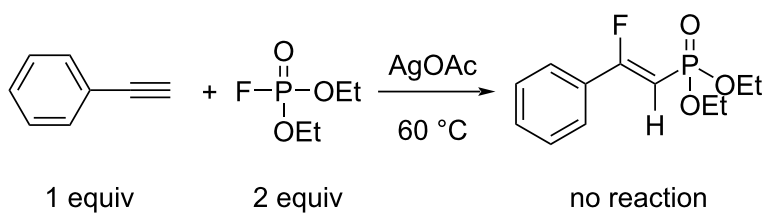

Scheme 6: Attempted use of a suspected phosphonofluorination intermediate to synthesize a $\beta$-fluorovinylphosphonate.

substrate scope and excellent functional group tolerance, this simple protocol may represent a general, one-step approach for the preparation of $\beta$-fluorophosphonate frameworks for the use in medicinal chemistry.

\section{Supporting Information}

\section{Supporting Information File 1}

Experimental procedures, full characterization of products, and NMR spectra.

[https://www.beilstein-journals.org/bjoc/content/ supplementary/1860-5397-16-258-S1.pdf]

\section{Funding}

We are grateful to NSFC-21772218, State Key Laboratory of Organometallic Chemistry, Shanghai Institute of Organic Chemistry, Chinese Academy of Sciences for financial support.

\section{ORCID ${ }^{\circledR}$ iDs}

Yajing Zhang - https://orcid.org/0000-0003-3333-8879

\section{References}

1. Wang, W.; Jasinski, J.; Hammond, G. B.; Xu, B. Angew. Chem. 2010, 122, 7405-7410. doi:10.1002/ange.201003593

2. Schuler, M.; Silva, F.; Bobbio, C.; Tessier, A.; Gouverneur, V. Angew. Chem., Int. Ed. 2008, 47, 7927-7930. doi:10.1002/anie.200802162

3. Mankad, N. P.; Toste, F. D. Chem. Sci. 2012, 3, 72-76. doi:10.1039/c1sc00515d

4. Akana, J. A.; Bhattacharyya, K. X.; Müller, P.; Sadighi, J. P. J. Am. Chem. Soc. 2007, 129, 7736-7737. doi:10.1021/ja0723784

5. Romanenko, V. D.; Kukhar, V. P. Chem. Rev. 2006, 106, 3868-3935. doi:10.1021/cr051000q

6. Jiao, X.-Y.; Bentrude, W. G. J. Am. Chem. Soc. 1999, 121, 6088-6089. doi:10.1021/ja984460s

7. Palacios, F.; Ochoa de Retana, A. M.; Pascual, S.; Oyarzabal, J. J. Org. Chem. 2004, 69, 8767-8774. doi:10.1021/jo048682m

8. Nguyen, T. T.; Koh, M. J.; Shen, X.; Romiti, F.; Schrock, R. R.; Hoveyda, A. H. Science 2016, 352, 569-575. doi:10.1126/science.aaf4622

9. Koh, M. J.; Nguyen, T. T.; Zhang, H.; Schrock, R. R.; Hoveyda, A. H. Nature 2016, 531, 459-465. doi:10.1038/nature17396

10. Hu, J.; Han, X.; Yuan, Y.; Shi, Z. Angew. Chem., Int. Ed. 2017, 56, 13342-13346. doi:10.1002/anie.201708224

11. Sakaguchi, H.; Uetake, Y.; Ohashi, M.; Niwa, T.; Ogoshi, S.; Hosoya, T. J. Am. Chem. Soc. 2017, 139, 12855-12862. doi:10.1021/jacs.7b08343

12. Liu, T.-L.; Wu, J.; Zhao, Y. Chem. Sci. 2017, 8, 3885-3890. doi:10.1039/c7sc00483d

13. Liu, Q.; Shen, X.; Ni, C.; Hu, J. Angew. Chem., Int. Ed. 2017, 56 619-623. doi:10.1002/anie.201610127 
14. Liu, Z.; Yang, L.; Zhang, K.; Chen, W.; Yu, T.; Wang, L.; Gao, W.; Tang, B. Org. Lett. 2020, 22, 2081-2086.

doi:10.1021/acs.orglett.0c00575

15. Dai, C.; Wang, J.; Deng, S.; Zhou, C.; Zhang, W.; Zhu, Q.; Tang, X. RSC Adv. 2017, 7, 36112-36116. doi:10.1039/c7ra07105a

16. Fu, H.; Shang, J.-Q.; Yang, T.; Shen, Y.; Gao, C.-Z.; Li, Y.-M. Org. Lett. 2018, 20, 489-492. doi:10.1021/acs.orglett.7b03922

17. Wang, J.; Xiong, H.-Y.; Petit, E.; Bailly, L.; Pannecoucke, X.; Poisson, T.; Besset, T. Chem. Commun. 2019, 55, 8784-8787. doi:10.1039/c9cc01851d

18. Liang, S.; Jiang, L.; Yi, W.-b.; Wei, J. Org. Lett. 2018, 20, 7024-7028. doi:10.1021/acs.orglett.8b02929

19. Gao, M.; Xu, B. Org. Lett. 2016, 18, 4746-4749. doi:10.1021/acs.orglett.6b02464

20. Zhao, M.; Shan, C.-C.; Wang, Z.-L.; Yang, C.; Fu, Y.; Xu, Y.-H. Org. Lett. 2019, 21, 6016-6020. doi:10.1021/acs.orglett.9b02160

21. Pan, S.; Li, H.; Huang, Y.; Xu, X.-H.; Qing, F.-L. Org. Lett. 2017, 19, 3247-3250. doi:10.1021/acs.orglett.7b01366

22. Zhu, L.; Yu, H.; Guo, Q.; Chen, Q.; Xu, Z.; Wang, R. Org. Lett. 2015, 17, 1978-1981. doi:10.1021/acs.orglett.5b00728

23. Tian, Q.; Chen, B.; Zhang, G. Green Chem. 2016, 18, 6236-6240. doi:10.1039/c6gc02656g

24. Zhang, C.; Li, Z.; Zhu, L.; Yu, L.; Wang, Z.; Li, C. J. Am. Chem. Soc. 2013, 135, 14082-14085. doi:10.1021/ja408031s

25. Sun, B.; Yin, S.; Zhuang, X.; Jin, C.; Su, W. Org. Biomol. Chem. 2018, 16, 6017-6024. doi:10.1039/c8ob01348a

26. Lv, Y.; Sun, K.; Pu, W.; Mao, S.; Li, G.; Niu, J.; Chen, Q.; Wang, T. RSC Adv. 2016, 6, 93486-93490. doi:10.1039/c6ra22653a

27. Lai, J.; Tian, L.; Liang, Y.; Zhang, Y.; Xie, X.; Fang, B.; Tang, S. Chem. - Eur. J. 2015, 21, 14328-14331. doi:10.1002/chem.201502581

28. Wille, U. Chem. Rev. 2013, 113, 813-853. doi:10.1021/cr100359d

29. Gupta, A. K.; Acharya, J.; Dubey, D. K.; Kaushik, M. P.

J. Fluorine Chem. 2008, 129, 226-229. doi:10.1016/j.jfluchem.2007.11.008

30. Chen, Q.; Zeng, J.; Yan, X.; Huang, Y.; Wen, C.; Liu, X.; Zhang, K. J. Org. Chem. 2016, 81, 10043-10048. doi:10.1021/acs.joc.6b01932

\section{License and Terms}

This is an Open Access article under the terms of the Creative Commons Attribution License (https://creativecommons.org/licenses/by/4.0). Please note that the reuse, redistribution and reproduction in particular requires that the author(s) and source are credited and that individual graphics may be subject to special legal provisions.

The license is subject to the Beilstein Journal of Organic Chemistry terms and conditions: (https://www.beilstein-journals.org/bjoc/terms)

The definitive version of this article is the electronic one which can be found at: https://doi.org/10.3762/bjoc.16.258 